\title{
HUBUNGAN TINGKAT PENDIDIKAN DENGAN PENGETAHUAN ORANG TUA TENTANG PEMBERIAN ANTIPIRETIK PADA BALITA DEMAM SEBELUM BEROBAT
}

\author{
Al Haikal Habibi', Ratih Ayu Atika', Andri' \\ ${ }^{1}$ Program Studi Pendidikan Dokter, Fakultas Kedokteran, Universitas Abulyatama
}

\begin{abstract}
Determining Relationships Between Educational Level With Parent's Knowledge In Giving Antipyretics For Children With Fever Before Treatment At The Puskesmas. Fever is a symptom of disease with body temperature above normal. This causes anxiety in the elderly so that most parents will give antipyretic drugs so that the heat goes down, even though a fever is a symptom of a viral infection that sometimes does not require medical treatment to cure it. The purpose of this study was to determine the relationship of education level with parents' knowledge about giving antipyretics to toddlers with fever before seeking treatment at the puskesmas. The results of research conducted on 92 respondents showed $53 \%$ of parents have high knowledge about antipyretic administration. Data analysis using Chi-square test obtained $p=0.001$ for education level. The conclusion of this study is that there is a significant relationship between the level of education with parents' knowledge about giving antipyretics to children before treatment.
\end{abstract}

Keywords: Fever, Antipyretics, Parental Knowledge, Education

\begin{abstract}
Abstrak: Hubungan Tingkat Pendidikan dengan Pengetahuan Orang Tua tentang Pemberian Antipiretik pada Balita Demam sebelum Berobat di Puskesmas. Demam merupakan gejala timbulnya penyakit dengan suhu tubuh diatas normal. Hal ini menimbulkan kecemasan pada orang tua sehingga kebanyakan orang tua akan memberikan obat antipiretik agar panas turun, walaupun demam adalah gejala infeksi virus yang terkadang tidak memerlukan penanganan medis untuk menyembuhkannya. Tujuan penelitian ini adalah untuk mengetahui hubungan tingkat pendidikan dengan pengetahuan orang tua tentang pemberian antipiretik pada balita demam sebelum berobat di puskesmas. Hasil penelitian yang dilakukan terhadap 92 responden menunjukkan 53\% orang tua memiliki pengetahuan tinggi tentang pemberian antipiretik. Analisa data menggunakan ujiChi-square diperoleh $p=0,001$ untuk tingkat pendidikan. Kesimpulan penelitian ini adalah terdapat hubungan yang signifikan antara tingkat pendidikan dengan pengetahuan orang tua tentang pemberian antipiretik pada anak sebelum berobat.
\end{abstract}

Kata Kunci: Demam, Antipiretik, Pengetahuan Orang Tua, Pendidikan

\section{PENDAHULUAN}

Pengetahuan merupakan segala sesuatu yang diketahui setelah melakukan penginderaan terhadap objek tertentu dan sangat penting untuk terbentuknya tindakan seseorang (KBBI online, 2019), sehingga menurut peneliti pengetahuan menjadi landasan awal bagi orang tua dalam menangani kondisi demam pada anak yang tidak hanya didapatkan dari pendidikan formal melainkan bisa didapatkan dengan mengikuti seminar kesehatan yang diadakan oleh puskesmas setempat mengenai penatalaksanaan demam, pemberian antipiretik, dosis penggunaannya serta efek samping dari antipiretik.

Antipiretik adalah golongan obat yang digunakan untuk menurunkan panas (Mulyani, Soedibyo, \& Yulandari, 
2017). Pendapat peneliti umumnya orang tua menggunakan obat antipiretik untuk menurunkan panas pada anak. Sebagian besar orang tua merasa takut ketika suhu tubuh anaknya meningkat sehingga orang tua akan memberikan obat untuk menurunkan panas atau membawa anak ke puskesmas. Orang tua mempunyai persepsi apabila demam pada anak turun maka anak sudah sembuh (Cahyaningrum, 2016).

Demam dikenal sebagai gejala adanya suatu penyakit (Soedibyo \& Souvriyanti, 2016). Kebanyakan orang tua menganggap demam adalah penyakit yang harus disembuhkan, mereka biasanya mengompres atau memberikan obat agar panas turun, sehingga mereka merasa lega, tetapi virus penyakit tersebut tidaklah hilang karena penyakitnya akan tetap berlanjut tanpa penanganan (Sudibyo, 2020).

Pendidikan adalah proses pengubahan sikap dan tata laku seseorang atau kelompok orang dalam usaha mendewasakan manusia melalui upaya pengajaran dan pelatihan (Undang-Undang Republik Indonesia No.20 2003, 2003), menurut peneliti belajar ini akan meningkatkan pola pikir individu dalam menentukan suatu objek, hal ini sejalan dengan pengertian pengetahuan sehingga pendidikan menjadi tolak ukur kepada orang tua dalam menentukan tindakan awal yang di lakukan saat anak demam dalam pemberian antipiretik yang merupakan penatalaksanaan untuk mengatasi anak yang mengalami demam.

Di Indonesia, pada tahun 2016 Cahyaningrum melakukan penelitian di Puskesmas Kembaran I, Banyumas mendapatkan hasil sebagian besar orang tua melakukan penatalaksanaan anak demam dengan cara farmakologi yaitu sejumlah 53 responden (50\%) dari 106 responden Cahyaningrum (2016). Di aceh telah dilakukan penelitian oleh Sapitri pada tahun 2015 di Rumah Sakit Umum Daerah dr. Zainoel Abidin (RSUDZA), meyatakan bahwa mayoritas orang tua berpendidikan dasar dan menengah berpengetahuan rendah dalam memberikan antipiretik kepada anak demam, sedangkan orang tua berpendidikan tinggi memiliki pengetahuan tinggi dalam memberikan antipiretik kepada anak demam (Sapitri, 2015).

Tahun 2019 kunjungan pasien dengan gejala demam ke ruang Manajemen terpadu balita sakit (MTBS) Puskesmas Langsa Baro, Kota Langsa berjumlah 1140 pasien. Hal ini menunjukkan bahwasannya masih banyaknya pasien dengan gejala demam yang di bawa ke puskesmas (Dinas Kesehatan Kota Langsa, 2019). Oleh karena itu, peneliti ingin melakukan penelitian tentang tingkat pengetahuan orang tua terhadap pemberian antipiretik yang dilatar belakangi oleh tingkat pendidikan. Penelitian ini dilakukan di Puskesmas Langsa Baro.

\section{METODE}

Jenis dan rancangan penelitian ini adalah observasional deskriptif dengan desain cross sectional. Bertujuan untuk mengetahui hubungan tingkat pendidikan dengan pengetahuan orang tua tentang pemberian antipiretik pada balita demam sebelum berobat.

Penelitian dilaksanakan pada Februari-Juni tahun 2020 di Fakultas Kedokteran Universitas Abulyatama. Populasi yang dijadikan sampel dalam penelitian yaitu mahasiswa pre-klinik dan mahasiswa klinik program pendidikan dokter. Penentuan sampel dilakukan dengan menggunakan teknik purposive sampling.

Variabel yang diteliti terdiri atas variabel dependen, yaitu populasi mahasiswa yang menjadi sampel penelitian, dan variabel independen, yaitu profesionalisme, etika, altruisme, empati, dan kepemimpinan.

Instrumen pengumpulan data dilakukan dengan menggunakan data primer berupa lembar kuesioner yang disusun dalam bentuk e-form dan dibagikan secara daring kepada 
mahasiswa yang menjadi sampel dalam penelitian.

Analisis data dalam penelitian dilakukan dengan analisis univariat untuk memperoleh deskripsi frekuensi

HASIL

Penelitian ini dilakukan terhadap 92 orang tua yang membawa anaknya pada setiap variabel berupa status akademik, jenis kelamin dan tingkat profesionalisme, altruisme, etika, empati dan kepemimpinan.

dengan keluhan demam di ruang MTBS Puskesmas Langsa Baro.

\section{Analisa Univariat}

Data distribusi frekuensi karakteristik responden disajikan dalam tabel sebagai berikut:

Tabel 1. Karakteristik responden penelitian

\begin{tabular}{ccc}
\hline Penyuluhan Demam & Frekuensi & Persentase (\%) \\
\hline Pernah & 16 & 17,4 \\
\hline Tidak Pernah & 76 & 82,6
\end{tabular}

Tabel 1 menunjukkan bahwa $82,6 \%$ orang tua tidak pernah mengikuti penyuluhan demam.

Tabel 2. Distribusi frekuensi pengetahuan orang tua tentang pemberian antipiretik pada anak

\begin{tabular}{ccc}
\hline Pengetahuan Orang Tua & Frekuensi (n) & Persentase (\%) \\
\hline Rendah & 43 & 47 \\
\hline Tinggi & 49 & 53 \\
\hline Total & $\mathbf{9 2}$ & $\mathbf{1 0 0}$ \\
\hline
\end{tabular}

Tabel 2 menunjukkan bahwa 53\% orang tua yang membawa anaknya dengan gejala demam di ruang MTBS Puskesmas Langsa Baro berpengetahuan tinggi.

Berdasarkan hasil pengumpulan data yang dilakukan dengan wawancara menggunakan kuesioner, diperoleh skor masing-masing pertanyaan untuk variabel pengetahuan orang tua tentang pemberian antipiretik pada anak. Gambaran secara lengkap dan jelas diperlihatkan dalam tabel berikut :

Tabel 3. Gambaran skor pertanyaan untuk kuesioner pengetahuan orang tua tentang pemberian antipiretik pada anak

\begin{tabular}{|c|c|c|c|c|}
\hline \multirow{2}{*}{ Pengetahuan Orang Tua } & \multicolumn{2}{|c|}{ Tinggi } & \multicolumn{2}{|c|}{ Rendah } \\
\hline & $\mathbf{N}$ & $\%$ & $\mathrm{n}$ & $\%$ \\
\hline $\begin{array}{l}\text { - Pengukuran suhu tubuh paling akurat pada } \\
\text { anak }\end{array}$ & 26 & 28,2 & 66 & 71,8 \\
\hline $\begin{array}{l}\text { Tempat pengukuran menggunakan } \\
\text { termometer yang paling akurat }\end{array}$ & 1 & 1,0 & 91 & 99,0 \\
\hline - Suhu tubuh anak dikatakan demam & 52 & 56,5 & 40 & 43,5 \\
\hline $\begin{array}{l}\text { - Tindakan setelah demam anak terjadi (demam } \\
\text { ringan) }\end{array}$ & 5 & 5,5 & 87 & 94,5 \\
\hline - Kompres yang digunakan & 63 & 68,5 & 29 & 31,5 \\
\hline
\end{tabular}




\begin{tabular}{lcccc}
\hline - Kondisi anak dibawa ke dokter & 81 & 88,0 & 11 & 12,0 \\
- Suhu tubuh normal & 46 & 50,0 & 46 & 50,0 \\
- Penyebab panas anak & 23 & 25,0 & 69 & 75,0 \\
- Suhu tubuh untuk pemberian obat penurun & 36 & 39,2 & 56 & 60,8 \\
$\begin{array}{l}\text { panas pada anak yang demam } \\
\text { Jenis obat penurun panas }\end{array}$ & 90 & 97,9 & 2 & 2,1 \\
& & & & \\
- Efek samping dari obat penurun panas & 8 & 8,7 & 84 & 91,3 \\
- Penetapan dosis pemberian obat penurun & 91 & 99,0 & 1 & 1,0 \\
$\begin{array}{l}\text { panas } \\
\text { Sendok yang digunakan saat memberikan }\end{array}$ & 70 & 76,1 & 22 & 23,9 \\
$\begin{array}{l}\text { obat penurun panas pada anak } \\
\text { Sumber pengetahuan tentang dosis obat }\end{array}$ & 47 & 51,0 & 45 & 49,0 \\
$\begin{array}{l}\text { penurun panas } \\
\text { Tindakan apabila pemberian obat penurun }\end{array}$ & 81 & 88,0 & 11 & 12,0 \\
$\begin{array}{l}\text { panas gagal } \\
\text { Isi obat penurun panas yang diberikan }\end{array}$ & 14 & 15,2 & 78 & 84,8 \\
$\begin{array}{l}\text { Pendapat tentang pernyataan 'Demam yang } \\
\text { tinggi membutuhkan obat penurun panas } \\
\text { dengan dosis yang tinggi' }\end{array}$ & 91 & 99,0 & 1 & 1,0 \\
\hline
\end{tabular}

Berdasarkan tabel 3 dapat dilihat bahwa sebagian besar orang tua berpengetahuan rendah. $71,8 \%$ orang tua tidak mengetahui pengukuran suhu tubuh paling akurat pada anak, 99,0\% orang tua tidak mengetahui tempat pengukuran menggunakan termometer paling akurat, $94,5 \%$ orang tua tidak mengetahui tindakan setelah demam anak terjadi (demam ringan), 75,0\% orang tua tidak mengetahui penyebab panas anak, $60,8 \%$ orang tua tidak mengetahui suhu tubuh untuk pemberian obat penurun panas pada anak yang demam, $91,3 \%$ orang tua tidak mengetahui efek samping dari obat penurun panas, serta $84,8 \%$ orang tua tidak mengetahui isi obat penurun panas yang diberikan.

Tabel 4. Distribusi frekuensi pendidikan orang tua

\begin{tabular}{lcc}
\hline Pendidikan & Frekuensi (n) & Persentase (\%) \\
\hline Dasar & 11 & 12,0 \\
Menengah & 47 & 51,0 \\
Tinggi & 34 & 37,0 \\
\hline Total & $\mathbf{9 2}$ & $\mathbf{1 0 0}$ \\
\hline
\end{tabular}

Tabel 4 menunjukkan bahwa $51,0 \%$ orang tua yang membawa anaknya dengan keluhan demam di ruang MTBS Puskesmas Langsa Baro berpendidikan menengah.

\section{Analisa Bivariat}

Analisa bivariat dilakukan untuk mengetahui hubungan antara variabel terikat dan variabel bebas. Adapun analisa bivariat yang digunakan dalam penelitian ini adalah sebagai berikut :

Hubungan tingkat pendidikan dengan pengetahuan orang tua tentang pemberian antipiretik pada sebelum berobat 


Tabel 5. Hubungan tingkat pendidikan dengan pengetahuan orang tua
tentang pemberian antipiretik pada anak sebelum berobat

\section{Berdasarkan}

tabel

menunjukkan bahwa mayoritas orang tua berpendidikan dasar $(91,0 \%)$ dan menengah $(59,6 \%)$ berpengetahuan rendah serta $85,2 \%$ orang tua berpendidikan tinggi memiliki pengetahuan tinggi.

Hasil uji statistik menggunakan uji Chi-square untuk variabel tingkat

\section{PEMBAHASAN}

Riset sebelumnya menemukan separuh dari ayah dan sepertiga dari ibu balita dengan kejang demam memiliki pengetahuan yang tidak tepat tentang definisi demam. Sebagian besar responden memiliki pengetahuan yang buruk terkait suhu minimal untuk pemberian obat atau melalui mandi seka. Orang tua juga memiliki pengetahuan yang jelek terkait frekuensi pengecekan suhu badan pada anak dengan demam dan pemberian antipiretik (Alivian, Purnamasari, \& Purwandar, 2013).

Hasil analisa data menggunakan uji Kolmogorov-Smirnov pada 92 responden menunjukkan nilai $p=0,002$ $<$ a 0,05 yang berarti bahwa terdapat hubungan yang signifikan antara tingkat pendidikan dengan pengetahuan orang tua tentang pemberian antipiretik pada anak sebelum berobat. Hal ini berarti semakin tinggi tingkat pendidikan orang tua maka semakin tinggi pengetahuannya.

$$
\text { Sejalan dengan yang }
$$

dikemukakann Notoatmodjo bahwa semakin tinggi tingkat pendidikan seseorang maka orang tersebut juga pendidikan menunjukkan nilai $p=0,001<a 0,05$. Ini berarti bahwa terdapat hubungan yang signifikan antara tingkat pendidikan dengan pengetahuan orang tua tentang pemberian antipiretik pada anak sebelum berobat.

semakin mudah menerima informasi dan semakin banyak informasi yang didapat semakin tinggi pengetahuan seseorang (Notoatmodjo, 2012). Penelitian Hayati juga menunjukkan orang tua dengan tingkat pendidikan sedang $(53,8 \%)$ dan tinggi $(15,4 \%)$ memiliki tindakan yang baik dalam penatalaksanaan demam, dikarenakan banyaknya pengetahuan yang didapat selama pendidikan dan memiliki jangkauan luas terhadap informasi mengenai demam (Hayati, 2014).

Penelitian ini menunjukkan bahwa tingkat pendidikan orang tua berpengaruh terhadap pengetahuan orang tua dalam menangani demam pada balitanya, karena orang tua dengan tingkat pendidikan dasar kurang memiliki kemampuan dalam menangani keadaan demam. Oleh sebab itu pentingnya dilakukan penyuluhan kesehatan mengenai penanganan demam yang menjangkau seluruh masyarakat, khususnya dengan pendidikan menengah kebawah dengan cara yang lebih mudah di pahami sehingga membuat responden lebih kompeten dalam penangan demam pada balitanya. 


\section{KESIMPULAN}

Berdasarkan hasil penelitian dan analisa data terhadap hubungan tingkat pendidikan dengan pengetahuan orang tua tentang pemberian antipiretik pada anak sebelum berobat, peneliti mengambil kesimpulan terdapat hubungan yang signifikan antara pengetahuan orang tua tentang pemberian antipiretik pada anak sebelum berobat dengan tingkat pendidikan.

\section{DAFTAR PUSTAKA}

Alivian, G. N., Purnamasari, M. D., Purwandari, H. (2013). Training manajemen demam di rumah untuk meningkatkan pengetahuan dan keterampilan ibu/pengasuh (Bachelor's thesis). Universitas Jenderal Soedirman, Banyumas, Indonesia.

Cahyaningrum, E. D. (2016). Penatalaksanaan anak demam oleh orang tua di puskesmas kembaran I banyumas. Viva Med, 9(2), 1-13.

Dinas Kesehatan Kota Langsa. (2019). Profil kesehatan kota Langsa.

Hayati, H. (2014). Hubungan tingkat pengetahuan ibu terhadap penatalaksanaan demam pada anak di desa air hitam kecamatan lima puluh kabupaten batubara (Bachelor's thesis). Universitas Sumatera Utara, Medan, Indonesia.

Kamus besar bahasa Indonesia online. (2019). Diakses dari https://kbbi.web.id/tahu.

Mulyani, D. I., Soedibyo, S., Yulandari, I. (2017). Persepsi Orang Tua Mengenai Demam dan Penggunaan

\section{SARAN}

Berdasarkan penelitian yang telah dilakukan, peneliti menyarankan Memberikan edukasi kepada orang tua melalui pemasangan banner, pamflet, atau spanduk mengenai pentingnya pengetahuan tentang efek samping, dosis, serta bahaya mengkonsumsi obat penurun panas tanpa indikasi yang jelas.

Antipiretik : Studi Potong Lintang di RSUD Malingping dan RSUPN Cipto Mangunkusumo. Departemen I/mu Kesehatan Anak, 44(10), 677-683.

Notoatmodjo, S. (2012). Pendidikan dan perilaku kesehatan. Jakarta, Indonesia : Rineka Cipta.

Undang-Undang Republik Indonesia No.20 Tahun 2003. (2003)

Sapitri, A. I. (2015). Hubungan tingkat pendidikan ,pendidikan, dan pekerjaan dengan pengetahuan orang tua tentang pemberian antipiretik pada anak sebelum berobat (Bachelor's thesis). Universitas Syiah Kuala, Banda Aceh, Indonesia.

Soedibyo, S., Souvriyanti, E. (2016). Gambaran persepsi orang tua tentang penggunaan antipiretik sebagai obat demam. Sari Pediatri, $8(2)$, 142-146. http://dx.doi.org/10.14238/sp8.2. 2006.142-6

Sudibyo, D. G. (2020). Pengetahuan ibu dan cara penanganan demam pada anak. Jurnal Farmasi Komunitas, 7(2), 69-76. 